\title{
Caso de aplicación de análisis de estados contables: indicadores económicos y financieros para la toma decisiones en pymes
}

\author{
Application case of financial statement analysis: economic and financial \\ indicators for decision making in SMEs \\ Caso de aplicação de Análise de Demonstrações Contábeis: indicadores \\ económicos e financeiros para a toma de decisões nas PMEs
}

\section{Julia Edith Cristóbal}

Facultad de Ciencias Económicas, Univer-

sidad Nacional del Litoral, Argentina.

E-mail: jcristobal@rectorado.unl.edu.ar

Fecha de recepción: 30/10/2017

Fecha de aceptación: 07/05/2018

Palabras clave

- Análisis de estados contables

- Utilidad

- Información contable

\section{Resumen}

La información contenida en los estados contables, en principio de uso externo, puede transformarse en el input de una serie de herramientas que se desarrollarán en el presente trabajo. Se espera que la información contable resulte más útil para la toma de decisiones de los usuarios internos. A partir del análisis de estados contables se propone desarrollar una serie de ratios e información que permita a la organización analizar las causas y los efectos de los datos contenidos en los estados contables, y comparar esta información con la obtenida en años anteriores, con la de otras organizaciones e incluso con datos del sector económico donde se desempeña.

Se desarrolla un estudio de caso y se analizan los estados contables de una empresa tomada como modelo, aplicando las herramientas del análisis horizontal y vertical para el análisis de la estructura patrimonial; y el análisis a través de ratios para la estructura económica y financiera. Finalmente, se propone un modelo de informe que sirva como herramienta para el profesional contable que le permita presentar a sus clientes un resumen de los datos más relevantes y exponer las conclusiones del análisis a modo de diagnóstico sobre el ejercicio cerrado, como de pronóstico para ejercicios futuros. 
Keywords

- Financial statement analysis

- Profit

- Accounting information

\begin{abstract}
The information provided by financial statements, which are mainly for external use, can become the input of a series of tools that will be developed in this research work. It is expected that accounting information will be more useful for internal users' decision-making process. Based on financial statements analysis, the aim is to develop a series of ratios and information that will allow the organization to analyze the causes and effects of the data contained in the financial statements, and to compare this information with that obtained in previous years, with data from other organizations and even with information from the economic sector where it operates.

A case study is described, analyzing the financial statements of a company taken as an example, through the application of tools of horizontal and vertical analysis for the analysis of the patrimonial structure and of analysis through ratios for the economic and financial structure. Finally, a report model is proposed with the aim of providing the accounting professional with a tool that will allow them to present to their clients a summary of the most relevant data and to explain the conclusions of the analysis as both a diagnosis of the closed exercise and a prediction for future years.
\end{abstract}

\section{Resumo}

A informação contida nas Demonstrações Contábeis, no começo de uso externo, pode se transformar no input de uma série de ferramentas que se desenvolverão no presente trabalho. Espera-se que a informação contábil seja mais útil para a toma de decisões dos usuários internos. A partir da Análise de Demonstrações Contábeis propõe-se desenvolver uma série de indicadores e informação que permita à organização analisar as causas e os efeitos dos dados conteúdos nas Demonstrações Contábeis, e confrontar esta informação com a obtida em anos anteriores, com a de outras organizações, e inclusive com dados do setor económico onde se desempenha.

Desenvolve-se um estudo de caso, analisando as Demonstrações Contábeis de uma empresa tomada como modelo, aplicando as ferramentas da análise horizontal e vertical para a análise da estrutura patrimonial; e a análise através de indicadores para a estrutura económica e financeira. Finalmente propõe-se um modelo de informe que sirva como ferramenta para o profissional contábil, que lhe permita apresentar a seus clientes um resumo dos dados mais relevantes, e expor as conclusões da análise como diagnóstico sobre 0 exercício fechado, como de prognóstico para exercícios futuros. 